\title{
COST ANALYSIS IN HIGHER EDUCATION OF RIBHUVAN UNIVERSITY
}

\author{
Minraj Paudel \\ Lecturer, Central Department of Education, Department of Economics Education, \\ Kathmandu, TU. \\ Corresponding author: minrajpaudel19@gmail.com
}

\begin{abstract}
The study analyzes the direct private and social cost of higher education in Tribhuvan University (TU) of Nepal. Post-positivist approach and survey methods with descriptive and explanatory design have been used, and both qualitative and quantitative data were collected from closed and semi-closed questionnaires. Simple random, stratified and purposive sampling techniques have been used. After the study, it is found that girls are more expensive than boys by 2.52 percent in the case of direct private non-institutional educational costs. Furthermore, if any student wants to study the master level under TU, s/he must invest NRs 3,08,858, NRs 3,43,170, NRs 3,43,370, NRs 3,75,843, NRs 5,18,477 and NRs 4,57,695 to get the degree from central department of Education, Nepali, English, Management, Zoology and Chemistry respectively as direct private cost up to complete this educational cycle. Except capital cost, the government of Nepal has burdened 61.82 percent and 38.18 percent by the household of higher education in TU, Nepal.
\end{abstract}

Keywords: private cost - social cost - higher education - post-positivism - mixed method

\section{INTRODUCTION}

Higher education is the sign of development in the country and it helps in preserving and developing all types of heritage, producing competent manpower in the global context and encourages and promotes research in the different areas of education (Upadhyay, 2018). In the context of Nepal, Tribhuvan University is the largest university and it was established in 1959 AD. Since then, it has taken the sole responsibility of providing higher education in the country. It has five Institutes (Engineering, Agriculture and Animal Science, Medicine, Forestry, and Science and Technology), and 
four Faculties (Humanities and Social Sciences, Management, Education and Law). The university has 62 constituent campuses (directly managed and operated by the University) and more than 1,000 affiliated campuses (Bista, Sharma \& Raby, 2019).

Educational costs are the sum of total expense incurred by public and private sectors. It is a measure of what the government, donor agencies and students/parents have to give up in order to educate an individual or a group of people. It refers to the amount spent on education by the individual student's parents during the academic year (Khandagale \& Pandya, 2014). It can be divided into social and private costs of education. Social costs refer to costs expended by the school/college on educational inputs and services. They are usually divided recurrent and capital costs for accounting purposes. Recurrent costs are the costs of educational inputs which is expended on salaries, employment benefits and supplementary benefits instructional materials, teaching aids, college supplies, minor repair and regular maintenance, utilities, and student welfare (Tsang, 1995), and capital cost is expended on construction sectors like buildings, play-grounds etc. Private cost is made by the students/parents. It is also divided into direct private and indirect private cost. Direct private cost is the total expenditure incurred by the households and it is directly related to instruction like fee and non-fee. Likewise, indirect private cost indicates the student's time which could have been utilized in an alternative way (Psacharopoulos \& Woodhall, 1995).

Higher education comprises all post-secondary education, training and research guidance at educational institutions such as universities that are authorized as institutions of higher education by state authorities (JICA, 2020). It is linked with better chances to get a good job in the labor market for many people. Therefore, students or parents seem to be ready to invest time and money (Lugaz \& Grauwe, 2018). In it, both social and private investment are incurred, and it highly contributes to economic development and raises the incomes of the poor as much as investment in physical capital does (Akpotu, 2008). Basically, cost of higher education is guided by human capital theory, is developed by Gary Becker in 1964 AD (Na, 2012). This theory believes that students have a series of choices on higher education and they take decision to make investments on the basis of productive capacities-knowledge, understandings, talents, and skills-possessed. This theory also believes that expenditures on education is depended on quality of education, health and other activities that augment these productive 
capacities (Josh \& Paulsen, 2001). According to Toutkoushian (2001), the economic behavior of colleges and universities is related with the theory of firm. These academic institutions apply the business models and use inputs e.g. faculty, students, machinery, land etc. to provide services to customers e.g. students and produce skilled manpower (p. 13).

Government of Nepal has been financing in higher education through public educational policies. It allocated 9 to 17 percent budget to education sector in different fiscal years, and among it, 56 to 63 percent budget goes to school level (pre-primary, primary and secondary level) and 17 to 24 percent budget goes to informal education (Ministry of Finance, 2075). In gist, 73 to 87 percent budget is invested in both school level and informal sectors, and remained budget only 12 to 27 percent of total is invested in higher education. Therefore, on the basis of this figure, it can be said that government investment in higher education of Nepal is very low. It means, private sector like students/parents have bore the large portion of education costs.

\section{Statement of the problems}

According to Bray (1999), it is usually seen that other educational costs such as; tuition, annual and stationery charges and, similarly, registration charge, board exam charge, exam form charge, exam central charge and project work charge, university certificate charge, transcript charge, library charge etc. are also incurred by students. In the case of government based colleges of Nepal, educational costs are shared by government as well as students/parents. Basically, teaching and nonteaching staffs' salary is incurred by government of Nepal and some of maintenance, construction and research based costs are provided by University Grant Commission of Nepal. How much the government and the private sector invest in education depends on the level of income. Large number of students are living around the poverty line, so, they cannot afford the high cost of education. Because, number of absolute poor people is 18.7 percent and number of multi-dimensional poor people is 28.6 percent in Nepal (Ministry of Finance, 2076) but the average nominal income of poorest 20 percent people is Rs $15,888.00$ annually and poverty line income is Rs 19,262.00 annually (CBS, 2011). Therefore, a question is often raised that how much amounts has been invested by the government of Nepal and the private sector (students/parents) in higher education of Nepal. This is the main problem of the present study. 


\section{Objectives of the study}

The aim of this study is to analyze the direct private and social costs of higher education in Nepal. The aim is broken as (a) to analyze the direct private costs of higher education and (b) to analyze the direct social costs of higher education.

\section{Significance of the study}

Cost of higher education is being a matter of discussion among academics, academicians, concerned authorities of government, donor agencies, students/parents and other concerned persons, because they believe that higher education gives high private benefits, and gives low social benefits. Therefore, students/parents and government invest in higher education as direct cost. In this context, the study has provided the information about direct private and social cost of education for those concerned persons who are and will be interested to compare with job earning. Some concerned persons are accusing to the program designers of higher education that if donor agencies have advised to launch any type of higher education programs they immediately say 'yes' to launch these imposed programs without any preparation, and such type of activities have taken place in Nepal. Therefore, this study will somewhat be useful for those persons who are directly involved in making the higher educational cost and financing policy and designing higher education program.

\section{REVIEW OF LITERATURE}

Costs of education in economies are incurred at two domains: the private and the public domains, which may also respectively be referred to as individual and institutional domains. Costs of education incurred at individual domain include costs on education incurred by the pupils, and or by their parents or guardians, such as on books, stationery, fees, hostel, uniforms, transport, etc. The institutional costs of education, also known as costs of supply of education, mainly include the recurring costs, e.g., expenditure on teachers' salaries, salaries of the non-teaching staff, scholarships, stipends, etc., and the non-recurring costs which include expenditure on purchase of buildings, furniture, equipment, etc. The sum of the costs of education incurred at the individual and the institutional domains, net of transfers such as fees, scholarships and stipends, gives the social costs of education (Tilak, 1985). 
According to Hollands \& Levin, the decision makers can use costs analysis to assess the resources required and costs of implementing a new program, to inform monitoring, accountability, and resource use of ongoing programs, to determine whether resources are being distributed equitably across sites and participants, to inform decisions regarding scale of program implementation and level of services provided, to compare several programs to help select the most effective one for students, relative to its cost, to balance the costs of an education program against the expected results to determine whether it represents a wise investment of resources, and to compare several programs to weigh costs against how well each program meets stakeholder needs (Hollands \& Levin, 2017).

Ismail, Awang \& Noor have completed one research on title 'analysis of private and social costs of education in Malaysia: an overview' in 2016 AD. They concluded that the cost of private primary schools varies according to the type of school. The abolition of school fees is not a significant reduction in the economic burden of financing education. Based on the items of cost involved, it clearly shows that the cost of private education fees to be borne by the parents remains higher. The financial resources at University level loans or scholarships were insufficient to cover the cost. Thus, some students resort to taking up part-time jobs or seeking additional financial assistance from parents to bear the cost. Fees and living expenses are the main components of overall student expenditure. In fact, for city-campus universities, the cost of living is much higher (Ismail, Awang \& Noor, 2016).

Yi et al have completed one research on title 'Dropping out: Why are students leaving junior high in China's poor rural areas?' in 2012 AD. They concluded that economic burden to be borne by the parents also determine the length and the level of schooling of their children. Further, they said that although the government's policy of reducing tuition and fees for junior high students may be necessary to solve the dropout problem (Yi et al, 2012).

\section{METHODOLOGY}

In this study, post-positivist approach has been used. It is somewhat subjective and has close relationship with research participant (Acharya, 2018). Its ontology, epistemology, methodology and axiology are critical realities, modified subjective, modified experimental and value free continuously (Creswell, 2014). This study follows the descriptive and 
explanatory research design. Both qualitative and quantitative data were used in this study. Primary data for analyzing direct private cost were collected from sampled students (respondents) by using mixed questionnaire survey form which had been pre-tested before of the beginning of the research. And, secondary data for analyzing direct social cost were collected from sampled Central Departments and Principal Office of Central Campus.

The study site of this study was Central Campus, Kirpipur of TU, but this study was limited within the six central departments like Central Department of Education, Nepali, English, Management, Zoology and Chemistry. Simple random, stratified and purposive sampling methods were used to choose the study site and respondents like Central Department of Education and Management was chosen from Faculty of Education and Management respectively using purposive sampling technique because of there was only one Central Department into each Faculty, but Central Department of Nepal and English were taken from 22 Central Departments under the Faculty of Humanities and Social Sciences, and Central Department of Zoology and Chemistry were taken from 13 Central Departments under the Institute of Science and Technology using simple random sampling technique. Similarly, heads of sampled Central Departments, deans of sampled Faculties and Institutes and account officers of sampled Central Departments, Faculties, Institute, Central Library and Exam Control Office of TU were selected by purposive sampling techniques.

Likewise, stratified sampling technique was used to choose the students as respondents. All students who were studying in master degree under semester system as regular programmes under the Central Campus, Kirtipur was assumed as the population for this study. Total number of students who were studying in fourth semester, they were 450, 250, 20, 50, 55 and 60 (Central Departments, 2075) in Central Department of Education, Management, Nepali, English, Zoology and Chemistry respectively. Among them, 20/20 students were selected by stratified random sampling technique, but census technique had been used to select 20 students from Central Department of Nepali because there were only 20 students. The same number is taken from sampled Central Departments because it makes easy to compare and draw the results. The study unit of this research was students who were studying in the fourth semester in master level at Central Departments. 
Table 1: Sampled Faculties, Central Departments and number of students (2075)

\begin{tabular}{lllllll}
\hline Faculties & Central & Study & \multicolumn{3}{l}{ Sampled Students } & Percentage \\
& Departments & Population & Boys & Girls & Total & \\
\hline Education & Education & 450 & 10 & 10 & 20 & 4.45 \\
Humanities and & Nepali & 20 & 9 & 11 & 20 & 100.00 \\
Social Science & English & 50 & 10 & 10 & 20 & 40.00 \\
Management & Management & 250 & 10 & 10 & 20 & 8.00 \\
Science and & Zoology & 55 & 11 & 9 & 20 & 36.36 \\
Technology & Chemistry & 60 & 10 & 10 & 20 & 33.34 \\
\hline Total & & 885 & 60 & 60 & 120 & 13.56 \\
\hline
\end{tabular}

Source: Respective central departments - 2076

The collected data were analyzed using descriptive tools such as average or mean, percentage, tables and figures, and then the results were interpreted. Total Direct Private Cost (TDPC) is the sum of Institutional Cost (IC) and Non-institutional Cost (NC), and for that, the formula TDPC $=I C+N C$ was used; and, the Total Direct Social Cost (TDSC) is the sum of Operating/current Cost (OC) and Capital Cost (KC), and for that, the formula of $T D S C=O C+K C$ was used. Similarly, Direct Private Unit Cost (DPUC) is obtained by dividing the TDPC by the number of sampled students (n), for that, the formula $D P U C=T D P C / n$ was used; and Direct Social Unit Cost (DSUC) is calculated by dividing the TDSC by the total number of students $(\mathrm{N})$, and for that, the formula $D S U C=T D S C / N$ was used.

To calculate the costs of higher education, some methodological assumptions were made in this study that students complete the degree within a fixed/given year and there is an ideal school year. Finally, calculated values were shown in Table and Figure, and, the results were interpreted.

\section{RESULT AND DISCUSSION}

Cost of higher education can be analyzed as direct and indirect costs. The indirect costs are often called as the opportunity costs of education, but in this study, it is not analyzed. This title is presented in subtitles of direct private and social cost of higher education on the basis its objectives. Educational expenses paid by households like students or parents are private costs and the total expenses incurred by the public authorities like government, donor agencies and other social institutions are social costs. 
Direct private cost is divided into institutional and non-institutional and both are incurred by students/parents to get, and social cost is incurred by government to provide the higher education.

\section{Direct private cost in higher education}

If students/parents directly pay to cash counter of college or department and other account office of university for admission and tuition, transportation, term exam, educational tour, coaching, computer class, name registration, thesis, character certificate, recommendation letter, campus stationary, identity card, library card, library late, college absent, term exam, exam center, practicum, entrance exam, practical exam etc. are assumed direct private institutional cost of higher education.

In TU, annual and tuition fee for first to fourth semesters are NRs 56,976.00, NRs 38,000.00, NRs 42,000.00, NRs 46,725.00, 98,815.00 and NRs 102,100.00 in Central Department of Education, Nepali, English, Management, Zoology and Chemistry respectively.

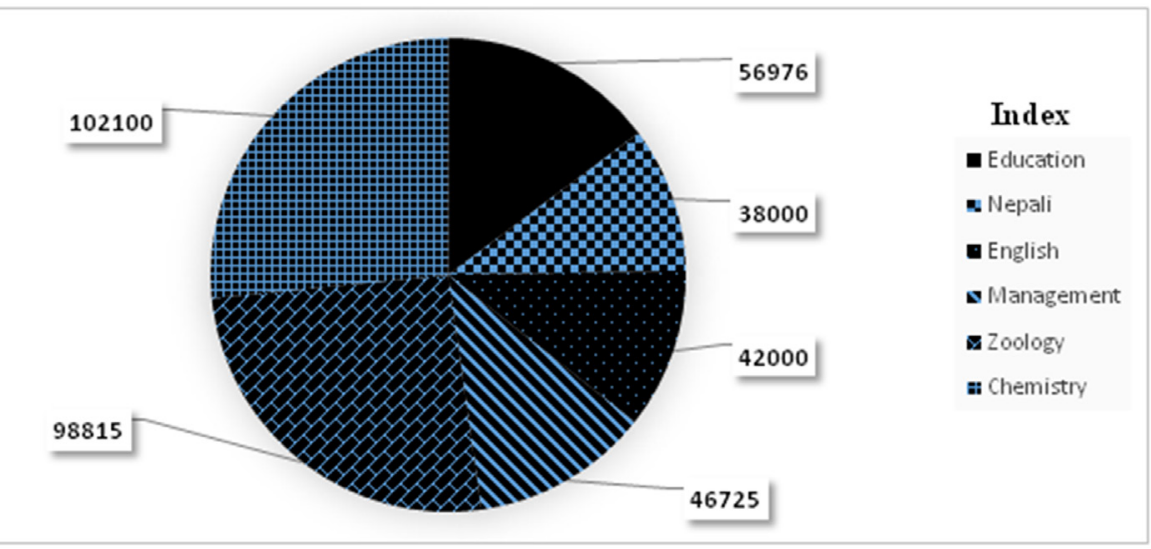

Figure 1: Institutional cost in higher education of TU (2075, in Rs)

Source: Field study - 2076

Students should pay NRs 3,500.00, NRs 2,800.00, NRs 7,000.00, NRs 8,000.00, NRs 8,150.00 and NRs 10,000.00 for thesis and charges of orientation, proposal viva, pre-viva and final viva of thesis are included under it; and should pay NRs 2,050.00, NRs, 2,030.00, NRs 2,550.00, NRs 2,550.00, NRs 2,030.00 and NRs 2,615.00 in title of entrance exam, character certificate and recommendation letter charge in aforesaid departments respectively. Students who study in faculty of education should pay NRs 2,500.00 for teaching practice. 
University related direct private institutional cost covers that cost which students have to pay to the Dean's Office, Central Library and Controller of Examinations. In these title, students have paid NRs 8,600.00, NRs 8450.00, NRs 9800.00, and NRs 9,800.00 in Faculty of Education, Humanities and Social Science, Management and Science and Technology respectively.

The total private institutional cost of higher education is NRs $73,626.00$, NRs $51,280.00$, NRs $60,000.00$, NRs 67,075.00, NRs $118,815.00$ and NRs 124,515.00 in Central Department of Education, Nepali, English, Management, Zoology and Chemistry respectively in TU. The lowest cost is in central department of Nepali and highest is in Chemistry and which is 2.43 time high. It is seen that science discipline is more expensive than others.

Non-institutional cost of higher education is the next important part and costs of text books, reference books, all type of stationary, college bag, college uniform, shoes, college tiffin, co-curricular activities, photocopy and printing of study materials, e-mail \& internet, computer as a study material, college transportation, coaching and tuition (outside the college), student welfare, educational donation, help in festival, picnic program, field trip and educational tour etc. are included under it.

Per-student annual average cost in this sector is NRs 117,616.00, NRs 145,945.00, NRs 141,685.00, NRs 154,384.00, NRs 199,841.00 and NRs 166,590.00 for Central Department of Education, Nepali, English, Management, Zoology and Chemistry respectively.

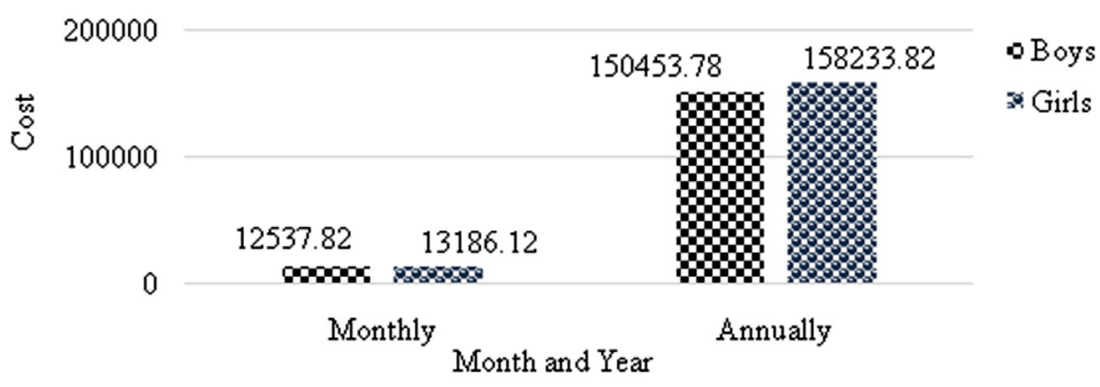

Figure 2: Gender and non-institutional cost in higher education (2075, in NRs)

Source: Field survey - 2076.

The researcher had collected data on the basis of gender to solve the query that who are more expensive among boys or girls? It is found that 
girls are more expensive than boys. In the study site, it is found that on an average, one student has spent NRs 154,344.00 per year, but one boy has spent NRs 150,454.00 and one girl has spent NRs 158,234.00 in a year to stay in Kathmandu as a students. Here, girls' expenditure is higher than boys by NRs 7,780.00 (5.17\%). Likewise, one boy should manage NRs 12,538.00 and one girl should manage NRs 13,186.00 as non-institutional cost of higher education for one month to live in Kirtipur as a student.

All types of direct private cost are categorized into institutional and non-institutional cost which is incurred by students/parents, and among them, some amount has been paid to college and university and some amount spent within and outside college and university is called the total direct private cost of higher education. In the case of TU, it is found that this type of cost is differ on the basis of departments.

Table 1: Annual per-student total direct private cost in higher education of TU (2075, in NRs)

\begin{tabular}{lllllll}
\hline Cost Items & Education & Nepali & English & Management & Zoology & Chemistry \\
\hline Institutional & 36,813 & 25,640 & 30,000 & 33,538 & 59,408 & 62,258 \\
Non-institutional & 117,616 & 145,945 & 141,685 & 154,384 & 199,841 & 166,590 \\
\hline Total & $\mathbf{1 5 4 4 2 9}$ & 171585 & 171685 & 187922 & 259249 & 228848 \\
\hline
\end{tabular}

Source: Field survey - 2076

On the basis of Table 1, it can be said that one student must manage NRs 154,429.00, NRs 171,585.00, NRs 171,685.00, NRs 187,922.00, NRs $259,249.00$ and NRs 228,848.00 as annual direct private cost of higher education to achieve master degree from Central Department of Education, Nepali, English, Management, Zoology and Chemistry respectively of Central Campus, Kirtipur under the TU, Nepal. Among these amount, the lowest cost is NRs 154,429.00 of Central Department of Education and highest is NRs 259,249.00 of Central Department of Zoology, and this amount is high by NRs $104,820.00$ or 1.68 time. Other things is that students of science and technology are more expensive than others.

\section{Direct social cost in higher education}

The social cost of higher education is sum the total current and capital costs which is incurred by the government, public institutions, donor agencies, schools/universities and commissions, and it is also called the public costs of education. But, opportunity cost or earnings foregone is not 
included in the computation of the total social costs. In this research, private cost has been presented in separate title above, and public costs of higher education has only been taken as social cost. Nepal government allocates some budget to develop the higher education. Sampled departments also achieve that type of budget because these are functioning under the government based campus of TU.

Table 2: Total direct social cost in higher education of TU (2075, in NRs)

\begin{tabular}{llll}
\hline Departments & Operating Cost & Capital Cost & Total Cost \\
\hline Education & $6,80,59,628$ & $22,66,000$ & $7,03,25,628$ \\
Nepali & $2,09,46,900$ & $2,66,000$ & $2,12,12,900$ \\
English & $2,13,08,940$ & $2,66,000$ & $2,15,74,940$ \\
Management & $2,00,43,340$ & $1,99,66,000$ & $4,00,09,340$ \\
Zoology & $1,26,54,960$ & $45,33,000$ & $1,71,87,960$ \\
Chemistry & $2,12,48,000$ & $12,66,000$ & $2,25,14,000$ \\
\hline Total & $16,42,61,768$ & $2,85,63,000$ & $19,28,24,768$ \\
\hline Percentage & 85.19 & 14.81 & 100 \\
\hline
\end{tabular}

Source: Principal Office of Central Campus, TU, 2076.

The data shown in Table 2 say that government of Nepal has spent total of NRs 19,28,24,768.00 in academic year 2075 including operating and capital costs, and among it, 85.19 percent is operating and 14.81 percent is capital cost. Capital cost is not a short-run cost and its impact or returns remains up to long-run.

\section{Unit cost of higher education in TU}

The unit cost of higher education represents the annual cost per student. Private unit cost is calculated from the total private cost of the respective department divided by the sampled number of students of the concerned department, and the social unit cost also is calculated from the total social cost of the respective department divided by the total number of students of the concerned departments. In this research, the sampled students were 120 (20 from each department) and total students were 1110, and of them, 625, 42, 102, 275, 28, and 38 are in Central Department of Education, Nepali, English, Management, Zoology and Chemistry respectively in the time of data collection. On the basis of aforesaid total direct private and social cost and number of students, the unit cost of higher education was calculated which have been mentioned in Table 3 . 
Table 3: Direct private and social unit costs of higher education in TU (2075, in NRs)

\begin{tabular}{|c|c|c|c|c|}
\hline \multirow{2}{*}{ Departments } & \multicolumn{2}{|c|}{ Social Unit Cost } & \multicolumn{2}{|c|}{ Private Unit Cost } \\
\hline & Annual & For Two Years & Annual & For Two Years \\
\hline Education & 112,521 & 225,042 & 154,429 & $3,08,858$ \\
\hline Nepali & 505,069 & $1,010,138$ & 171,585 & $3,43,170$ \\
\hline English & 211,519 & 423,038 & 171,685 & $3,43,370$ \\
\hline Management & 228,625 & 457,250 & 187,922 & $3,75,844$ \\
\hline Zoology & 613,856 & $1,227,712$ & 259,249 & $5,18,498$ \\
\hline Chemistry & 592,474 & $1,184,948$ & 228,848 & $4,57,696$ \\
\hline Total & $2,264,064$ & $4,528,128$ & $11,73,718$ & $2,347,436$ \\
\hline Percentage & & 65.86 & & 34.14 \\
\hline
\end{tabular}

Source: Calculated from Table 1 and Table 2

On the basis of Table 3, it can be said that 65.86 percent burden of costs of higher education has been incurred by the government and 34.14 percent by the private (students/parents) sector. Likewise, if one lower graduated wants to study upper graduation level or master level in Central Department of Education under the Faculty of Education of TU, s/he must manage the NRs $308,858.00$ as direct private cost up to complete this educational cycle. This amount can be seen differ in each department like that NRs 343,170.00, NRs 343,370.00, NRs 375,844.00, NRs 518,498.00 and NRs 457,696.00 are in Central Department of Nepali, English, Management, Zoology and Chemistry respectively.

The comparison between the government's current costs and the institutional costs of the sampled students showed that government had incurred 78.19 percent, and the private sector had incurred 21.81 percent costs of the higher education. Similarly, the comparison between the government's current costs and the sum value of institutional and noninstitutional costs of the private sector also showed that government and private sector had incurred 43.06 percent and 56.93 percent respectively. In order to compare the sum value of government's current and capital costs with the sum value of private sector's institutional and non-institutional costs, government's contribution as capital costs should be reduced in the current costs. For that, effect of capital costs was assumed of 80 years and this value of costs was reduced. By doing this, it was seen that the 
government and private sectors had contributed 43.11 percent and 56.89 percent as the costs of higher education.

\section{CONCLUSIONS}

Education is core element for the development of a country but its cost has been increasing over the years around the world. In the case of Nepal, cost of higher education is incurred by the household or students/ parents and government. The total private institutional costs of higher education up to complete this cycle are NRs 73,626.00, NRs 51,280.00, NRs 60,000.00, NRs 67,075.00, NRs 118,815.00 and NRs 124,515.00, and annual average per-student non-institutional costs are NRs 117,616.00, NRs 145,945.00, NRs 141,685.00, NRs 154,384.00, NRs 199,841.00 and NRs 166,590.00 in Central Department of Education, Nepali, English, Management, Zoology and Chemistry respectively. It is found that girls are more expensive than boys by $5.17 \%$. Social cost is the next important part for higher education. In $2075 \mathrm{BS}$, the government of Nepal has spent total of NRs 192,824,768.00, and among it, 85.19 percent and 14.81 percent are operating and capital costs respectively in sampled departments. Except capital cost, the government of Nepal and private sector have burdened 43.06 percent and 56.93 percent costs of the higher education respectively. If included the government's capital costs these percentage values are changed as 43.11 and 56.89 respectively.

Finally, if any student wants to study the master level in TU, s/he must manage the NRs 308,858.00, NRs 343,170.00, NRs 343,370.00, NRs 375,844.00, NRs 518,498.00 and NRs 457,695.00 for Central Department of Education, Nepali, English, Management, Zoology and Chemistry respectively as direct private cost both institutional and non-institutional up to complete this educational cycle under TU, Nepal.

\section{ACKNOWLEDGMENTS}

I would like to acknowledge Prof. Dr. Dhurba Raj Shiwakoti, TU, Prof. Dr. Surya Bahadur Thapa (Head of Department of Economics Education, Central Department of Education) TU, and Prof. Dr. Umesh Kumar Mandal (Executive Director of Research Center of Tribhuvan University), and the anonymous referees for their valuable comments and suggestions. 


\section{REFERENCES}

Acharya, B.R. (2018). Diversity in mathematics education. Kathmandu: Pinacal publications. (pp. 125-128).

Akpotu, N.E. (2008). Social cost analysis of secondary education in South West Nigeria (1996-2001). Journal of Social Science. 16(1): 2733. http://citeseerx.ist.psu.edu/ viewdoc/download?doi=10.1.1.597 $.1894 \&$ rep $=$ rep $1 \&$ type $=$ pdf.

Bista, K., Sharma, S. \& Raby, R.L. (2019). Telling stories, generating perspectives: Local-global dynamics in Nepalese higher education. In: Krishna Bista, Shyam Sharma and Rosalind Latiner Raby (eds.) Higher Education in Nepal: Perspectives and Policies. Routledge. pp. 3-22. https://www.researchgate.net/publication/335383610.

Bockerman, P., Haapanen, M. \& Jepsen, C. (2018). Labor-market returns to higher vocational schooling (IZA discussion paper No. 11734). IZA institute of labor economics. http://hdl.handle.net/10419/185194 (Assessed 26.08.2020).

Bray, M. (1999). The private costs of public schooling: Household and community financing of primary education in Cambodia. Paris: International institute for educational planning (IIEP), UNESCO. (pp. 215-221).

CBS (2011). Nepal living standards survey-2010/11 (vol. II). Kathmandu: Central Bureau of Statistics, National Planning Commission Secretariat, Government of Nepal.

Creswell, J.W. (2014). Research design: Qualitative, quantitative and mixed methods approaches (4th ed.), London: SAGE publication inc. (pp. 255-260).

Hollands, F.M. \& Levin, H.M. (2017). The critical importance of costs for education. Center for benefit-cost studies of education, Columbia University. https://files.eric.ed.gov/fulltext/ED574634.pdf , Assessed: 25.08.2020.

Ismail, R., Awang, M. \& Noor, M.A.M. (2016). Analysis of private and social costs of education in Malaysia: An overview. International Journal of Academic Research in Business and Social Sciences. 6(11): 24-37. https://doi.org/10.6007/JJARBSS/v6-i11/2371. 
JICA. (2020). Overview of highereducation. Japan International Cooperation Agency. https://www.jica.go.jp/english/searchResults/index.html. Assessed: 29.08.2020).

Josh, E.P.St. \& Paulsen, M.B. (2001). The finance of higher education in the twenty-first century. In: Michael B. Paulsen and John C. Smart (eds.) The finance of higher education: Theory, research, policy, and practice. New York: Agathon press. (pp. 4434-454).

Khandagale, V.S. \& Pandya, S. (2014). Private cost of education and academic achievement of students: An analysis by school types. IOSR Journal of Humanities and Social Science (IOSRJHSS).19(2): 39-43. https://doi.org/10.9790/0837-19223943.

Lugaz, C. \& Grauwe, A.D. (2018). Improving school financing: The use and usefulness of school grants (Lessons from East Asia and the Pacific). Paris: International institute for educational planning (IIEP), UNESCO. (pp. 88-90).

MoF. (2076 BS). Economic survey - 2075/76. Kathmandu: Ministry of Finance, Government of Nepal.

MoF. (2077 BS). Economic survey - 2076/77. Kathmandu: Ministry of Finance, Government of Nepal.

Na, L. (2012). An introduction on Gary Becker's 'human capital theory'. In: Min Zhu (ed.) Business, economics, financial sciences, and management, New York: Springer (pp. 437-439).

Psacharopoulos, G. \& Woodhall, M. (1995). Education for development (An analysis of investment choices). Washington DC: The World Bank.

Tilak, J.B.G. (1985). Analysis of costs of education in India (Occasional paper No. 10). National Institute of educational planning and administration. https://www.researchgate.net/ publication/234680086. Assessed: 12.09.2020.

Toutkoushian, R.K. (2001). Trends in revenues and expenditures for public and private higher education. In: Michael B. Paulsen and John C. Smart (eds.) The finance of higher education: Theory, research, policy, and practice. New York: Agathon press. (p. 21).

Tsang, M.C. (1995). Private and public costs of schooling in developing nations. In: Martin Carnoy (ed.) International encyclopedia of economics of education. United Kingdom: Pergamon. 
Upadhyay, J.P. (2018). Higher education in Nepal. Pravaha Journal. 24(1): 96-108. https://doi.org/10.3126/pravaha.v24i1.20229.

Yi, H. Zhang, L, Lou, R, Shi, Y, Mo, D, Chen, X \& et al. (2012). Dropping out: Why are students leaving junior high in china's poor rural areas? International Journal of Educational Development. 32(4): 555-563. https://doi.org/10.1016/j.ijedudev.2011.09.002.

Zhang, S., Greg J. \& Soukup, J. (2016). A study of rural Chinese students' educational expenses, academic performance, and extracurricular activities. Journal of Chinese Economics. 4(1): 13-28. http:// journals.sfu.ca/nwchp/index.php. 